Металлофиз. новейшие технол. / Metallofiz. Noveishie Tekhnol. () 2015 ИМФ (Институт металлофизики 2015 , т. 37, № 5, сс. 605-613

Оттиски доступны непосредственно от издателя

им. Г. В. Курдюмова НАН Украины)

Фотокопирование разрешено только

Напечатано в Украине.

в соответствии с лицензией

PACS numbers: 06.60.Vz, 61.80.Ba, 78.20.nd, 81.05.Bx, 81.20.Vj, 81.40.Tv

\title{
Analysis of Optical Radiation Emissions During GMAW Applications
}

\author{
A. Gursel and A. Kurt* \\ Duzce University Faculty of Engineering, \\ Department of Mechanical Engineering, \\ 81620 Düzce, Turkey \\ "Gazi University Faculty of Technology, \\ Department of Materials and Metallurgy, \\ 06500 Ankara, Turkey
}

The GMAW (Gas Metal Arc Welding) technique and its radiation emissions are examined in this study. Three commonly used materials in industry, SS304-type stainless steel, A36 low-carbon steel, and T6061 aluminium, are chosen for the tests. The welding is applied at $140 \mathrm{~A}$, and radiation types and luminosities are evaluated for each material. During the welding processes, ultraviolet radiation was the most frequently observed at all parameters; in addition, visible light and infrared radiation, 200-1000 $\mathrm{nm}$ on an optical scale, are recorded. The effects of electric currents on the photon energy rates are clearly exhibited. The wavelengths are similar on the SS304 and A36 materials, but higher photon energy and intensity are observed on SS304. Furthermore, for the T6061 aluminium material, the optical radiation emission and peak patterns are totally different from the others, with peaks spiking over the entire range of the optical scale.

В цій роботі вивчається газове дугове зварювання металевою електродою та випромінювання, що супроводжує цей процес. Для дослідження обрано три широко використовуваних у промисловості матеріяли: неіржавійна сталь типу SS304, низьковуглецева сталь A36 і алюміній T6061. Зварювання виконувалося при 140 А; для кожного матеріялу визначалися тип і яскравість випромінення. В процесі зварювання при всіх параметpax найбільш часто спостерігалося ультрафіолетове випромінення; крім цього, реєструвалися також видиме світло й інфрачервоне випромінення в оптичному діяпазоні 200-1000 нм. Ясно виявився вплив електричних токів на швидкість зміни енергії фотонів. Довжини хвиль виявилися близькими для матеріялів SS304 і А36, але більші енергія фотонів та інтенсивність спостерігалися для SS304. Крім того, для алюмінію Т6061 оптичне випромінення і структура піків, які розташовані в усьому оптичному діяпазоні, повністю відрізняються від решти. 
В данной работе изучается газовая дуговая сварка металлическим электродом и сопровождающее её излучение. Для исследования выбраны три широко используемые в промышленности материала: нержавеющая сталь типа SS304, низкоуглеродистая сталь А36 и алюминий T6061. Сварка производилась при 140 А; для каждого материала определялись тип и яркость излучения. В процессе сварки при всех параметрах наиболее часто наблюдалось ультрафиолетовое излучение; кроме того, регистрировались также видимый свет и инфракрасное излучение в оптическом диапазоне 200-1000 нм. Ясно проявилось влияние электрических токов на скорость изменения энергии фотонов. Длины волн оказались близкими для материалов SS304 и A36, но большая энергия фотонов и интенсивность наблюдались для SS304. Кроме того, для алюминия T6061 оптическое излучение и структура пиков, расположенных во всём оптическом диапазоне, полностью отличаются от остальных.

Key words: arc welding, GMAW (Gas Metal Arc Welding), welding radiation.

(Received December 19, 2014)

\section{INTRODUCTION}

Most arc welding and cutting processes, such as laser and torch welding, cutting, brazing, and soldering, produce a large quantity of radiation requiring precautionary measures. Some processes such as resistance welding and cold pressure welding ordinarily produce negligible quantities of radiant energy [1]. Welding arcs produce radiation; however, an insufficient number of detailed studies have been carried out based on parameters such as welding techniques, welded materials, and welding currents [2]. Arc light radiation is a complicated phenomenon involving several welding parameters [3]. Without understanding the essential mechanism, its utilization is based merely on subjective experience and assumptions [4].

The welding arc is a significant artificial source of radiation, producing mainly optical radiation [5]. Optical radiation is generated by welding arcs over a broad range, $200-1400 \mathrm{~nm}(0.2-1.4 \mu \mathrm{m})$, of wavelengths. Optical radiation consists of ultraviolet $(200-400 \mathrm{~nm})$, visible $(400-700 \mathrm{~nm})$ and infrared $(700-1400 \mathrm{~nm})$ radiation [6].

Radiation given off by the arc or flame is electromagnetic energy that may damage eyes and burn skin [7]. Broad-spectrum ultraviolet radiation (UVR) is known to be a human carcinogen [8]. The UV-C radiation from welding arcs can cause ocular and skin cancer as well as chromosomal and DNA damage [9]. An operator is able to see visible light (VIS) radiation; however, he cannot see ultraviolet (UV) or infrared (IR) radiation. Moreover, UV-A, VIS and IR radiation may reach the retina and can cause ocular injury [10]. Ultraviolet radiation also targets the anterior parts of the eye and may be associated with the development of acute and chronic symptoms [11]. 
Arc welding radiation produces direct adverse effects, including eye and skin damage, on the operators and nearby workers [12]. Consequently, welders have a higher than average risk of developing skin cancer and cataracts from biologically effective radiation [13]. Although it is known that welding arcs produce radiation, sufficiently detailed research has not been done on radiation with regard to welding parameters [2].

The intensity and wavelength of the energy produced depend on the welding parameters, including electrode and base metal composition, fluxes, and any coating or plating on the base material [1]. Ultraviolet radiation increases approximately as the square of the welding current. The visible brightness (luminance) of the arc increases at a much lower rate [14].

Welding radiation studies have provided data covering some welding parameters by measuring the energy, radiation dose, and determining limitations for health institutes [13]. Only a few studies have analysed the light produced by welding arcs. A welding arc is not a steady source of radiation; subsequently, this gives rise to calibration difficulties. Further research on welding radiation is needed in order to accurately cover all welding parameters, including materials and welding techniques [2]. This study focused only on GMAW (Gas Metal Arc Welding) and three materials commonly used in industry: aluminium, stainless steel and low-carbon steel. The GMAW is applied to test samples using 140 Ampere (A) electric current. During the welding process, the different radiation types were measured and analysed according to their wavelengths. A high amount of UV emission was detected. Optical radiation covering the entire ultraviolet band (UV-A, UV-B and UV-C), VIS and high-energy IR-A was observed for each test specimen.

\section{EXPERIMENTAL METHODOLOGY}

The test materials chosen for this study were SS304-type stainless steel (SS), A36 low-carbon steel and T6061 aluminum; their chemical compositions are given in Tables $1-3$.

The specimens were prepared as $5 \times 50 \times 200 \mathrm{~mm}^{3}$ samples and welded using the GMAW method. For the aluminium, Lincoln ER 4043L was used, for the stainless steel, Lincoln ER 308L, and for the low-carbon steel, E 6013; L56/56B electrode wires having a standard thickness of 0.030 were chosen for the study. The samples were welded using a Miller XMT $304 \mathrm{CC} / \mathrm{CV}$-type welding machine with an argon gas shield.

During the welding process, the radiation values were measured using the ZEISS MCS 501 UV-NIR spectrometer, the features of which are given in Table 4. For this study, the UV source was the welding arc; therefore, the photometer and spectrometer functions of the ZEISS MCS 501 UV-NIR, which sense and analyse light, were utilized. For 
TABLE 1. Chemical composition of SS304 stainless steel

\begin{tabular}{c|c|c|c|c|c|c|c|c}
\hline Element & $\mathrm{Cr}$ & $\mathrm{Ni}$ & $\mathrm{Mn}$ & $\mathrm{Si}$ & $\mathrm{C}$ & $\mathrm{P}$ & $\mathrm{S}$ & $\mathrm{Fe}$ \\
\hline \multirow{2}{*}{$\%$} & $18.0-$ & $8.0-$ & 2.0 & 1.0 & 0.08 & 0.045 & 0.030 & Remainder \\
& 20.0 & 10.50 & $\max$ & $\max$ & $\max$ & $\max$ & $\begin{array}{c}0.03 \\
\text { max }\end{array}$ & (a) \\
\hline
\end{tabular}

TABLE 2. Chemical composition of A36 (ATSM) low-carbon steel.

\begin{tabular}{c|c|c|c|c|c|c|c}
\hline Element & $\mathrm{Mn}$ & $\mathrm{Si}$ & $\mathrm{C}$ & $\mathrm{Cu}$ & $\mathrm{S}$ & $\mathrm{P}$ & $\mathrm{Fe}$ \\
\hline$\%$ & $1.03 \max$ & $0.28 \max$ & $0.25-0.29$ & $0.20 \max$ & $0.05 \max$ & $0.04 \max$ & Remainder \\
\hline
\end{tabular}

TABLE 3. Chemical composition of T6061 Aluminium.

\begin{tabular}{c|c|c|c|c|c|c|c|c|c|c}
\hline Element & $\mathrm{Ma}$ & $\mathrm{Fe}$ & $\mathrm{Si}$ & $\mathrm{Zn}$ & $\mathrm{Cu}$ & $\mathrm{Mn}$ & $\mathrm{Ti}$ & $\mathrm{Cr}$ & Other & $\mathrm{Al}$ \\
\hline \multirow{2}{*}{$\%$} & $0.8-$ & 0.7 & $0.4-$ & 0.25 & $0.15-$ & 0.15 & 0.15 & $0.04-$ & 0.15 & Remainder \\
& 1.2 & $\max$ & 0.8 & $\max$ & 0.4 & $\max$ & $\max$ & 0.35 & $\max$ & \\
\hline
\end{tabular}

measuring the $200-1000 \mathrm{~nm}$ wavelengths, a $1 / 3 \mathrm{sec}$ integration period was determined. The probe was positioned at a distance of $1 \mathrm{~m}$ from the arc and was connected to the spectrometer by fiber optic cable.

The spectral irradiance from the welding arc was observed and recorded by means of AspectPlus, ZEISS MCS 501 UV-NIR software. A screen view showing measured and recorded data can be seen in Fig. 1. The luminosity is seen on the vertical line as lumens $(\mathrm{lm})$ and the wavelength is seen on the horizontal line as nanometers $(\mathrm{nm})$.

The observed maximum and minimum optical radiation rates are indicated by the two lines at the top and bottom. The average rate taken into consideration is shown by the middle line (Fig. 1).

\section{RESULTS AND DISCUSSION}

In this study, radiation values were obtained from GMAW applications on three types of test materials. The electric voltage, based on the properties of the test materials, was determined as $27 \mathrm{~V}$ for the stainless steel and low-carbon steel, and as $20 \mathrm{~V}$ for the aluminium specimens. These values are seen in Figs. 2-5 as diagrams based on the materials and 140 A electric current values.

TABLE 4. ZEISS MCS 501 UV-NIR Spectrometer.

\begin{tabular}{c|c|c|c|c}
\hline Type & Resolution & Accuracy & Pixel No & $\lambda$-Range \\
\hline MCS 501 UV-NIR & $2.4 \mathrm{~nm}$ & $0.3 \mathrm{~nm}$ & $512 / 1024$ & $190-1015 \mathrm{~nm}$ \\
\hline
\end{tabular}




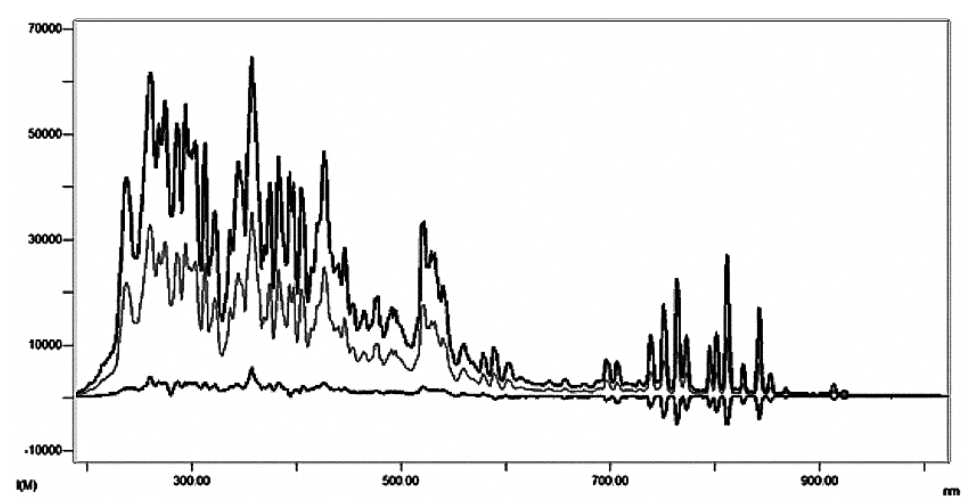

Fig. 1. View of the screen showing measured values as recorded by the software.

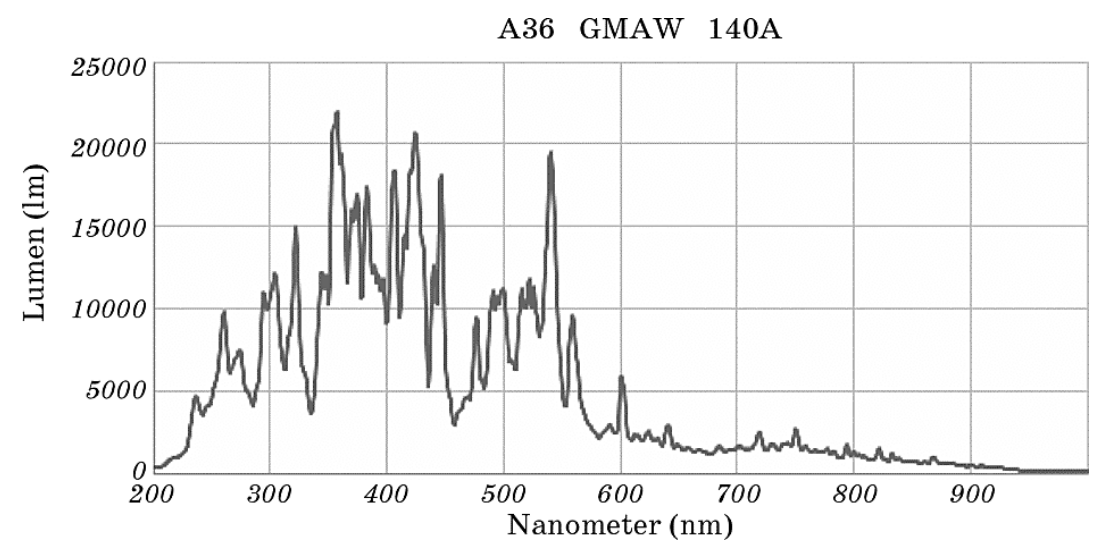

Fig. 2. Optical radiation values for A36 low-carbon steel.

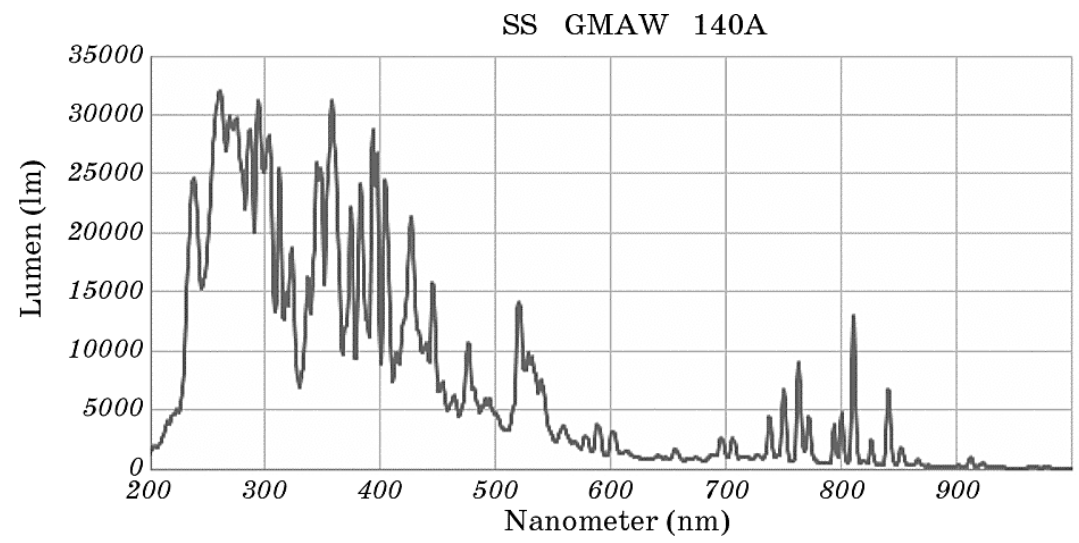

Fig. 3. Optical radiation values for SS304 stainless steel. 


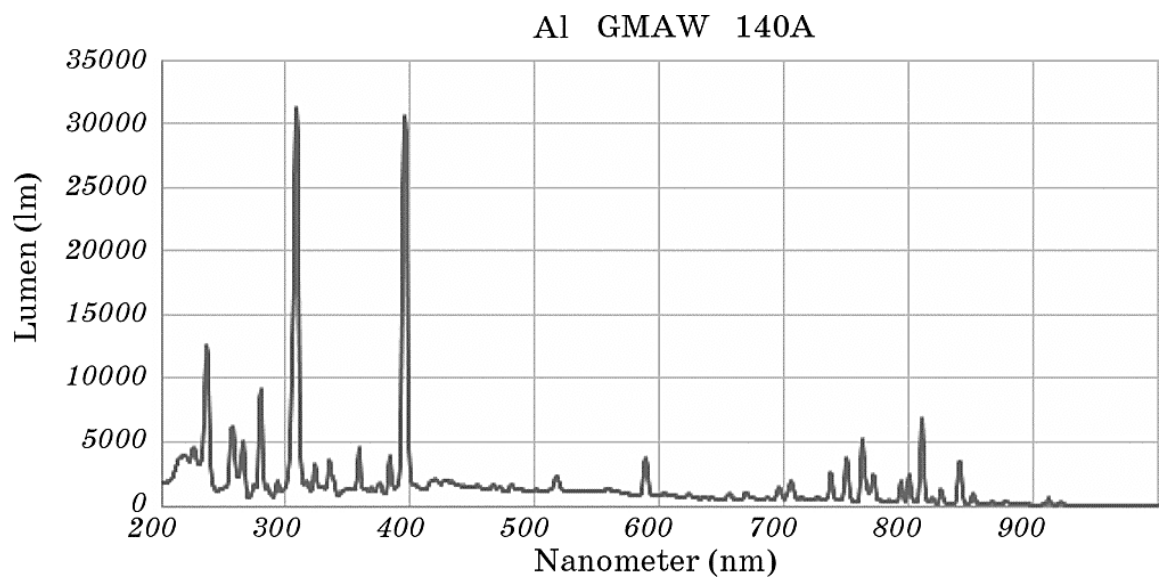

Fig. 4. Optical radiation values for T6061 aluminium.

The light was converted to an optical scale; the measurable intensity in this study was in a wavelength range of $200-1000 \mathrm{~nm}$.

For the low-carbon steel, the UV band was measurable between 200 and $400 \mathrm{~nm}$ (Fig. 2). The highest intensity of light was $350-550 \mathrm{~nm}$, which is the UV-A and VIS. Over $700 \mathrm{~nm}$ of IR radiation was observed, although it exhibited lower energy levels.

Among the materials exposed to GMAW applications, the highest energy level of radiation was observed on the stainless steel samples (Fig. 3). The highest intensity of radiation was $220-400 \mathrm{~nm}$, which is entirely in the UV band; IR energy was seen between 740 and $840 \mathrm{~nm}$. The luminosity reached over $32000 \mathrm{~lm}$.

As seen in Fig. 4, the optical radiation values for the Al GMAW applications were very different from those of the stainless steel and lowcarbon steel. The light was dispersed over the $200-850 \mathrm{~nm}$ wavelength range. These scattered wave ranges covered UV-A, UV-B, UV-C, VIS and $\mathrm{IR}$ radiation. On the $\mathrm{Al}$ specimen, the highest photon energy started from a range of $230-400 \mathrm{~nm}$ and the luminosity reached over 30000 $\operatorname{lm}$.

The comparison of arc lights for each of the test materials is shown in Fig. 5. The highest energy value is obtained from the stainless steel samples as luminosity and frequency. The lowest rates were obtained from the low-carbon A36 steel samples. The energy rates from the aluminium samples are dispersed throughout the entire optical scale, but were mostly concentrated in the UV band between 240 and $400 \mathrm{~nm}$, with some in the IR band. Thus, the material types and their compositions were shown to affect the radiation values [4].

For this study, the distance of the probe from the welding arc was $1 \mathrm{~m}$, whereas an operator is only a few centimetres away from the weld- 


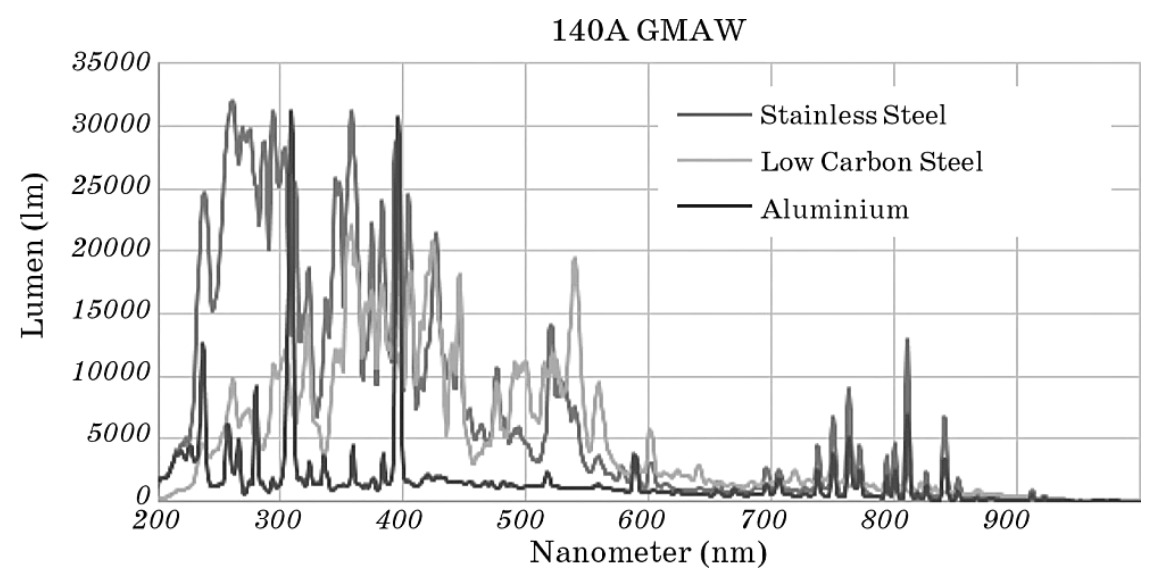

Fig. 5. Comparison of values for the three sample materials.

ing arc. Therefore, the influence of radiation energy upon the operator and his skin is much higher than that recorded above [14].

Measurements of the radiation levels of each of the test materials in this study were applied for comparison and analysis. All three materials were welded by the GMAW technique, at 140A electric current, and using an argon gas shield. The resulting types and amounts of radiation produced for each sample material differed significantly. The stainless steel produced more radiation energy and the aluminium elicited scattered graphics on the optical scale.

\section{SUMMARY}

This study attempted to determine the radiation emissions from GMAW arcs on different test materials. Values were obtained for each of the parameters and the following results and conclusions were observed.

1. Optical radiation, including UV, VIS, and IR, is generated by GMAW applications.

2. The energy input, which is based on the thermal conduction and fusion levels of the materials, also affects the radiation emissions as photon energy. With the increase of energy input, the photon intensity and radiation emissions also increase [1]. Higher light intensity was observed with the increase of the electric current magnitude.

3 . Inert argon shielding gas was applied in this study. For further studies, other types of shields based on different techniques could be investigated. The shields can affect the type and range of radiation from welding arcs [12].

4. The chemical composition of the welded materials is seen to affect 
the production and emission of radiation [4]. There is a need for future investigations of this aspect, including studies of other welding techniques, a variety of materials and other parameters.

5 . The highest intensity of radiation and frequency of energy with lower wavelengths occurred in the electromagnetic spectrum during the welding applications on the stainless steel sample [15].

6. During the GMAW applications, the aluminum materials produced values of radiation peaks ranging across the entire optical scale. The highest graphic peaks were seen in the UV and IR bands. In addition, the form of the aluminium graphic exhibited a different pattern from those of the values for the other materials [14].

7. The GMAW applications on low-carbon steel, stainless steel and aluminum samples resulted in the production of high optical radiation energy. The three materials produced different types and ranges of radiation. Lower frequency and photon energy are seen on the low-carbon steel specimen than on the other two specimens. Furthermore, the highest optical radiation energy $(200-400 \mathrm{~nm})$ and luminosity (over $32000 \mathrm{~lm}$ ) were obtained from the stainless steel sample.

\section{REFERENCES}

1. AWS-American Welding Society (AWS ), Safety and Health Fact Sheet, No. 2: 1 (2013).

2. A. Gursel and A. Kurt, Elektrik Ark Kaynaklarında Ortaya Çikan Ultraviyole Radyasyon Değerlerinin İnsan ve Çevre Sağlíği Üzerindeki Etkileri, 1. Uluslararasi Kaynak Teknolojileri Konferansi (Ankara: 2009).

3. T. D. Tenkate, Optical Radiation Hazards of Welding Arcs. Reviews on Environmental Health, 13, No. 3: 131 (1998).

4. P. J. Li and Y. M. Zhang, AWS-Welding Journal. Welding Research Supplement, 252 (2000).

5. ESH \& Q, Assessment of and Protection from Welding Arc Radiant Hazards, Jefferson Lab. Manual, Rev., 8.7-7 (2006).

6. M. H. Repacholi, Introduction to Non-Ionizing Radiations. ICNIRP Third International Non-Ionizing Radiation Workshop (Beden, Austria: 1996), p. 3.

7. A. J. Dixon and B. F. Dixon, The Medical Journal of Australia, 181, No. 3: 155 (2004).

8. NTP, Report on Carcinogens, Twelfth Edition 2011. U.S. National Toxicology Program, 1-5 (2011).

9. K. Cieminis, V. Ranceliene, K. Slekyte, and N. Tiunaitiene, Biologia, No. 1 (2001); ISNN 1392-0146.

10. CCOHS, Radiation and the Effects on Eyes and Skin.CCOHS-Canadian Centre for Occupational Health and Safety (2001).

11. IARC, Monographs on the Evaluation of Carcinogenic Risk to Humans, Chromium, Nickel and Welding, 1990. World Health OrganizationInternational Agency for Research on Cancer (Lyon, France: 1990), vol. 49.

12. T. L. Lyon, Welding Journal, 2, No. 12: 28 (2002).

13. IFA, Emission of UV Radiation During Arc Welding, 2011. Institut für 
Arbeitsschutz der Deutschen Gesetzlichen Unfallversicherung (2011).

14. A. Gursel and A. Kurt, Materials Testing, 56, No. 10: 826 (2014).

15. American Welding Society (AWS ), Safety and Health Fact Sheet, No. 26: 29 (2004). 